\title{
Local Wisdom in Sumbawa's Proverb, Indonesia
}

\author{
Novi Sri Wahyuni ${ }^{1}$
}

${ }^{1}$ Awardee of Indonesia Endowment Fund for Education ,Universitas Indonesia.

\section{ARTICLE INFO}

Keywords:

local genius; Sumbawa proverb's; denotation; connotation; semiotic

\begin{abstract}
Local wisdom is a very interesting culture of a society in Indonesia. One of the local wisdom in Indonesia is the Sumbawa community. The values of the wisdom of the Sumbawa people can be found in Sumbawa proverb. The Sumbawa proverb that is present in the Sumbawa community cannot be separated from the cultural background of the Sumbawa people. The cultural background of the community can affect the process of creating local wisdom. Semiotic linguistic studies can be used to examine the values of local wisdom in society. Semiotic is also very suitable for explaining culture. The method used in this study is qualitative. The theory used in this study is a semiotic theory of Rolland Barthes about denotation and connotation. The object of the study is Sumbawa's proverb in two levels based on Barthes's semiotics' theory: (1) Denotation: the most obvious meaning of the sign; (2) Connotation: the interaction between the sign that meets the feelings or emotions of the audience and its culture. Based on the results of Roland Barthes's semiotics through the process of denotation and connotation can be concluded that in Sumbawa proverb can be found the values of local wisdom such as the values of hard work, a relationship between human beings, a male and female character, and how is the relationship between men and women.
\end{abstract}

\section{Introduction}

Local wisdom in a community culture is very interesting, especially in Indonesia. Indonesia which consists of various ethnic groups has its own traditions and culture is an interesting study to explore. A semiotic linguistic study can be used to examine the values of local wisdom in a community. Wales said that local genius is the sum of the cultural characteristics which the vast majority of a people have in common as a result of their experiences in early life. The local wisdom of the Sumbawa people is the values of intelligence and wisdom that are produced based on experience and passed down from generation to generation. 
This is inseparable from the relationship between language and culture. In every language product, as in Proverbs, there are cultural values related to people's lives. The Sapir-Whorf hypothesis is the linguistic theory that the semantic structure of a language shapes or limits the ways in which a speaker forms conceptions of the world. Every culture has its own local wisdom. Kramsch (1998) stated that language expresses cultural reality, language embodies cultural reality, and language symbolizes cultural reality.

The local wisdom of the Sumbawa community can be found in the oral and written literature produced. In these literary works, there are many values of wisdom. In Sumbawa culture, many literary works can be extracted from wisdom values such as poetry, prose, and proverb. In Sumbawa proverb, many metaphors are found to compare or equalize two things. Lakof and Jhonson stated that metaphor is pervasive in everyday life, not just in language but in thought and action. Moon and Knowles (2006:3) stated that metaphor is a basic process in the formation of words and word meanings. Concepts and meanings are lexicalized, or expressed in words, through metaphor. Metaphors in Sumbawa proverb is used to express the thought of Sumbawa people. In this paper, we will discuss local wisdom in the Sumbawa proverb in terms of the study of semiotics. Research questions of this study are what values are contained in the proverb and how is the relationship between signifier and signified in the Sumbawa's proverb?

Proverbs are groups of words or sentences that remain in order, usually accentuating certain intentions (in proverbs including thimbles, expressions, and parables). In proverbs contain rules of human action, advice, principles of life, and others. The Sumbawa proverb is one of the local wisdom possessed by the Sumbawa community. Local wisdom is passed down from generation to generation. In Sumbawa's proverb uses a lot of proverbs that have an image of animals besides there are also those who use depictions of the state of nature and others. This cannot be separated from the cultural background of the Sumbawa people which caused the emergence of these characteristics in the Sumbawa's proverb.

A proverb is one of the cultural expressions created and related to the message contained. A semiotic function is to explain culture. The proverb created from the results of thoughts that have values.

\section{Theory and Methodology}

Semiotics is the study of signs. Semiotics can be used to understand how humans give meaning to various things that are sensed and felt (as part of a knowledge system). Humans always look for the meaning of what is around them and also humans give what meaning that happens to them.

In Barthes's semiology, denotation is the first level of significance system, while the connotation is the second level. Denotation is a commonly known meaning while connotation is a new meaning that is given by the sign user according to the wishes, background of knowledge, or new conventions that exist in society. According to Barthes, when the connotation has become steady, it will become a myth and a myth that has been established will develop into ideology. Hoed (2014) states that the connotation given by the user of the sign and the connotation concept used by Barthes is used to explain how cultural symptoms are seen as a sign of obtaining special meaning (connotation) from the community. The myth that has been considered normal and the only one will proceed to become an ideology. The following is a sign map of Rolland Barthes; 


\begin{tabular}{|c|c|}
\hline 1. Signifier & 2. Signified \\
\hline 3. Denotative sign & \\
\hline 4. Connotative signifier & 5. Connotative signified \\
\hline
\end{tabular}

Semiotic sign of Rolland Barthes

The method used in this study is a qualitative method because in this study it does not use statistics but uses descriptive and narrative. As Denzin and Lincoln (2000: 4) stated, qualitative research involves an interpretive approach to seeing the world. The role of qualitative research, in this case, is to learn everything in natural conditions, try to understand, or interpret phenomena in the context of the person who interprets them. In addition, Creswell (2010: 4) states that qualitative research is a method for exploring and understanding the meaning that a number of individuals or groups of people ascribed to social or humanitarian problems.

The data source used in this study is the Sumbawa's proverb book from the book of Adi Pranajaya (2012). The proverbs analyzed are Sumbawa proverbs that are still used by the Sumbawa people to this day. The author conducts data collection through literature studies from books and previous studies related to the local wisdom of the Sumbawa community. Data are classified and analyzed by Roland Barthes theory.

\section{Finding and Discussion}

Local wisdom values can be found in the Sumbawa proverb. These wisdom values contain life value messages about advice, recommendations, prohibitions, and others. The use of lexicons in the Sumbawa's proverb has a connection with the cultural background of the local community. In the proverb, it also uses a lot of metaphors to compare and equate humans with others. Here are some Sumbawa proverbs which are analyzed using Barthes's semiotics;

\section{PROVERB}

\section{Hard work values}

1. Ada sio ada daki

Dennotation: There is sweat, there is dirt

Connotation: When someone works hard then he/she will get results. Sio is interpreted

as a sweat which means that when there is a sweat it will have a dust. The local wisdom that contained in the proverb is that one must work hard first in order to get the desired results

Sio in the Sumbawa language means sweat, while daki is the remaining dust that mixes with sweat attached to the body. Sweat and dust in the human body are caused by humans working hard so that their bodies have sweat and dust. Sumbawa people use sio and daki parables because most of the livelihoods of the Sumbawa people are farming or as a farmer so that there is a proverb ada sio ada daki.

2. Mara tikes sowan oram

Denotation: Like a mouse holding a broom

Connotation: Mice are small animals which of course will be difficult if carrying brooms. This is likened to parents who are toiling to support their children 
Mara means like, tikes is a rat, sowan means to uphold and oram is a broom. In the proverb, it is described how parents who try to meet the needs of their children because of the responsibilities they endure so that they are equated with mice that uphold brooms, although it is very difficult to do due to all limitations, parents will always try to fulfill their responsibilities as parents to their children.

\section{The relationship between human beings}

1. Ajar bote entek kayu

Denotation: Teaching monkeys to climb trees

Connotation: Teaching people who are smarter about something is the same as teaching apes to climb trees.

Myth: Teaching smart people is futile because they are smarter and capable of doing anything without being told

In Sumbawa's proverb 'teaching monkeys to climb trees' (mengajar monyet memanjat pohon), the use of a monkey in the proverb is because monkey is a close animal in the life of the Sumbawa people, which is often found in the forests close to farmers' fields. Monkeys in Sumbawa's cognition are animals that are very clever in climbing trees

2. Patinang lempo ai

Denotation: The full jar

Connotation: Someone who has a lot of knowledge is likened to a jar that is fully

filled

The use of patinang (jars) in the proverb is because in ancient times Sumbawa people used jars in houses that served as a place to put water to drink so that in ancient times each house must have a large sized jar for storing drinking water

\section{Human character}

1. Bawa lading tumpil

Denotation: Bring a blunt knife

Connotation: Blunt knife can no longer be used to cut objects and has no function as before, so that the proverb is used to describe someone who interferes in other people's affairs even though they do not understand the problem is equated with a blunt knife

Sumbawa's proverb bawa lading tumpil means carrying a blunt knife. That proverb is still very often used by the Sumbawa people in their daily lives. The proverb is used to describe human characters who always want to interfere with other people's business.

\section{Male character}

1. Bukal ngayo

Denotation: Kelelawar (bats) ngayo

Connotation: As we know that bats are active at night. Therefore people who like to wander at night are equated with bats.

The word "ngayo" is one of the Sumbawa proverbs that describe a culture of the people of Sumbawa. Ngayo is one of the activities carried out by the Sumbawa community to help friends or neighbors who are harvesting in the fields. The term ngayo is still used today and besides that, the tradition still continues to be carried out today.

2. Yam boa tau sewai

Denotation: Men who talk a lot 
Connotation: The expression addressed to men who talk a lot is like a woman.

Myth: Men should not say much because of the myth in society that men don't talk much. Sumbawa community thinks that men who talk a lot are equated with women. The Sumbawa people's opinion about men that a man must be authoritative and not talk too much

\section{Female character}

1. Patis lalat

Denotation: Tame flies

Connotation: Flies when perched on objects or food, when they are approached, flies will fly immediately.

The woman who seems to want to be a man but when a man approaches her, she dodges it instead. Flies are used as an equation with women. When women approached by men, avoid them even though at first they don't avoid them. They (women) play hard to get.

\section{Relations between women and men}

1. Yam tima ketong Denotation: Like a bucket hanging on a rope Connotation: Timba is always paired with ropes and is never separated. This is used to describe a young couple who are in love

Tima in Sumbawa language is timba, ketong which means wrapped around. Lead and rope are used in Sumbawa worship because the two objects are things that can be found in every Sumbawa community house. Timba is used to extract water from wells where wells are one of the most important things that must be in the Sumbawa community's house to meet daily water needs

In the analysis above, nine proverbs Sumbawa have been explained. The proverbs analyzed are proverbs that are still used by Sumbawa community to this day. Proverbs are one of the local wisdoms that are owned by community of Sumbawa which are handed down from generation to generation.

\section{CONCLUSION}

The values of the wisdom of the Sumbawa people can be found in Sumbawa proverb. Based on the results of Roland Barthes's semiotic analysis through the stages of denotation and connotation, it can be concluded that in Sumbawa proverb can be found local wisdom values such as the values of hard work, relationships among men, male character, female character, and how the relationship between men and female. The creation of Sumbawa proverb cannot be separated from Sumbawa people cultural background because it influences the process of creating the proverb.

\section{REFERENCES}

Barthes, Roland, 1957, Mythologies, London, Paladin Books.

Creswell, John W. 2010. Research Design: Qualitative, Quantitative, and Mixed Methods Approach (Third Edition).

Denzin, K. Dezin and Y.S. Lincoln (Eds). 2000. Handbook of Qualitative Research.

California: Sage Publications

FalseZhao, Wen. 2012. An analysis of Social Proverbs from the Perspective of Cultural

Semiotics. In: Theory and Practice in Language Studies 2.10 (Oct 2012): 2073-2080.

Hoed, Benny H. 2014. Semiotik dan Dinamika Sosial Budaya. Jakarta: Komunitas Bambu. Knowles, Murray and Rosamund Moon. 2006. Introducing Metaphor. London and New York: 
Routledge.

Kramsch, C. (1998). Language and Culture. Oxford: Oxford University Press.

Lakoff, George dan Mark Johnson. 1980. Metaphor We Live By. London: The University of Chicago Press. Pranajaya, Adi. 2012. Peribahasa Bahasa Sumbawa. Jakarta: AP foundation.

Risager, Karen. 2006. Language and Culture: Global Flows and Local Complexity. UK:

Cromwell Press Ltd.

Smith, Philip. 2004. Cultural Theory: An Introduction. Oxford, UK: Blackwell Publishing. 